\title{
Beyond Frontiers and Borderlands: A Reexamination of Tsushima's/Taema-Do's Geopolitical Position in Fifteenth Century East Asia*
}

Isaac C.K. Tan**

\section{Introduction}

In January 2017, a five-year long dispute over the repatriation of a bronze Buddhist statue that was reportedly stolen from a Buddhist temple in the fishing hamlet of Kozuna, Tsushima, came to a close. Based on historical documents in Buseoksa Temple, the South Korean court ruled that the stolen statue should remain in the possession of the Korean temple as it had been taken by Japanese pirates several centuries earlier. ${ }^{1}$

* The author would like to extend his gratitude to the Associate Editor, Professor Leighanne Yuh, the two anonymous reviewers, and the managing editor, Lee Hwihyun, for their very detailed, constructive, and insightful comments in refining earlier drafts of the manuscript. Any errors that remain are solely the author's responsibility.

** Ph.D. candidate, Department of East Asian Languages and Cultures, Columbia University

1 Martin Fackler, “An Icon and a Symbol of Two Nations' Anger," New York Times, June 3, 2013, https://www.nytimes.com/2013/06/03/world/asia/japan-korea-dispu te-revived-by-statues-theft.html; Sang-Hun Choe, "South Korea Can Keep Buddhist Statue Stolen From Japan, Court Says," New York Times, January 26, 2017, https://www.nytimes.com/2017/01/26/world/asia/south-korea-japan-buddha-statue. $\mathrm{html}$. 
This incident is but one of many outstanding regional disputes-from sovereignty issues of control over outlying islands to the politics of nomenclature-where two contending powers overlap in hegemonic control for several centuries. Though military confrontations between Japan and Korea are a thing of the past, subtle sites of contention remain. For example, in the newly completed Busan International Ferry Terminal that opened in 2015, the signages indicating the ferry route from Busan to Tsushima was written as "Tsushima" in Katakana and "Taema-do" in Korean. ${ }^{2}$ This nuanced revelation suggests unresolved historical tensions on the legitimacy of sovereign control over Tsushima today.

This article looks at how Tsushima/Taema-do, ${ }^{3}$ situated approximately 90 miles away from the nearest Japanese city Fukuoka and just 30 miles away from Busan in South Korea, positioned itself in East Asian geopolitics in the fifteenth century. Tsushima/Taema-do is often described as situated at the periphery of Japan or at its borders, its territorial status shrouded in ambiguity and remained in flux, as negotiated by different actors in the region. However, this does not translate into a chaotic East Asian order where different political states constantly vied for power and control over neighboring territories. On the contrary, Tsushima/Taema-do presents a unique vantage point from which to examine the politics of fifteenth century East Asia. Not only had it been an island domain since the Warring States period (c. 1467-c. 1603), valued at 100,000 koku at the height of its power, but it was also the only domain that had the au-

2 Nakamura Yae, "Tsushima ni okeru chi' iki aidentiti saikōchiku-Chōsen tsūshinshi to ijin wo meguru sutōrīteringu wo chūshin ni," Irǒilmunhang yŏn'gu 99, no. 2 (November 2016): 19.

3 Tsushima was originally a single land mass until 1671 when the first of two canal constructions split the island into three. Referring to this set of islets as Tsushima reflects my acknowledgment of the current political outlook of Japanese sovereignty over the territory. However, this was not often the case in the time period of my investigation. Hence, I intend to use "Tsushima" and "Taema-do" interchangeably to reflect contemporaneous geopolitical dynamics. 
tonomy to engage with a foreign power until $1871 .^{4}$

Beginning with new archaeological discoveries in the late 1970s, a generation of young scholars championed novel historical approaches that ushered in a major historiographical shift in medieval Japanese diplomatic history-from the postwar research that approached regional interactions as an extension of national history (i.e., history of the Japanese archipelago) to one that focused on non-national and peripheral entities (i.e., privileging perspectives from the Sea of Japan/East Sea and maritime islands) in the 1980s. ${ }^{5}$ This trend of highlighting the importance of the cosmopolitan nature of peripheral territories rewrote mainstream narratives of medieval Japanese history; of particular relevance is how historians looked beyond political and economic factors in understanding crossstraits relations. For example, Araki investigated the rationale behind the Sō clan's diplomatic policies from the fourteenth to eighteenth century (i.e., the dispatchment of pseudo-diplomats - traders who impersonated as official envoys) by underlining the importance of the exchange of human and non-human resources, including trading goods and information. ${ }^{6}$

4 One koku is about 330 pounds. As cited in the 1678 edition of Edo-period publication Bukan [Compendium of Samurais], a popular compendium detailing all existing daimyos. See Tsuruta Kei, Tsushima kara mita Nitchō kankei (Tokyo: Yamakawa Shuppansha, 2006), 52.

5 For a succinct summary of Japanese historiography since the Second World War, see Seki Shūichi, Tsushima to wakō: Kyōkai ni ikiru chūsei bito (Tokyo: Koshi Shoin, 2012), 5-10. Some of the most prominent groundbreaking archaeological findings include the 1987 excavation of the ruins of the Kōrokan [Official Guesthouse for Foreign Emissaries] in Dazaifu, Kyushu and the discovery of a 1323 shipwreck of a Chinese trading ship bound for Hakata off the coast of Sinan county, South Korea in 1976. The 1980s was perceived as a watershed due to the passing of eminent Japanese scholar Mori Katsumi in 1981, as Enomoto notes that ironically it was after the death of Mori that new methodologies were published within Japanese academia. See Enomoto Wataru, Higashi Ajia kaiiki to Nitchū kōryū: 914 seiki (Tokyo: Yoshikawa Kōbunkan, 2007), 7-8. For Mori’s research, see especially the collection of his representative works published in 1975.

6 Araki Kazunori, Chūsei Tsushima Sōshi ryōgoku to Chōsen (Tokyo: Yamakawa 
Notwithstanding the abundance of official documents on Tsushima/Taema-do from the Edo period, the reverse holds true for the preTokugawa era. Nonetheless, the Chosŏn Wangjo Sillok [Veritable Records of Chosŏn Dynasty, hereafter referred to as CWS], which kept meticulous record of not just domestic politics but that of foreign correspondence, is perhaps the most important document to analyze the geopolitics of medieval East Asia. Moreover, scholars have also turned to private travel diaries of Korean and Japanese emissaries whenever available to corroborate official entries as well as to verify identities of individuals with different names as recorded in the various historical sources. ${ }^{7}$ The widespread practice of pseudo-official diplomatic institutions in East Asia, as mentioned in the earlier passage, thus posed a major challenge in comprehending official perspectives during the fifteenth century. Hence, to avoid making false claims from non-official sources that were passed off as government documents, when quoting primary sources outside of the CWS I have resorted to taking citations only from sources that were verified by preceding historians. Furthermore, as the premise of my research deals with the regional dimension of Tsushima/Taema-do, the CWS is by far the optimum primary source to investigate how the island negotiated its geopolitical position and how the various East Asian states accommodated its exclusivity as reflected in their official dealings.

Due to the centering of Tsushima in this article, I eschew conventional time frames that trace dynastic changes in the main hegemonic powers of the region. Rather, by recalibrating our standpoint of analyzing international relations, I underline the role played by local historical agents from Tsushima/Taema-do during several major historical ruptures that defined fifteenth century East Asian history. The ambiguous status of the island

Publishing Company, 2017).

7 On the importance of the CWS in medieval Japan historiography, see especially Murai Shōsuke, Chūsei wajin den (Tokyo: Iwanami Shoten, 1993), 7-8; Tanaka Takeo, Zenkindai no kokusai kōryū to gaikō bunsho (Tokyo: Yoshikawa Kōbunkan, 1996), 275-86. 
was skillfully accommodated by the two major spheres of power and authority—Chosŏn Korea and Muromachi/Ashikaga Japan-and allowed local players from Tsushima/Taema-do (specifically the ruling Sō 宗 clan), pirates (C. wōkòu; J. wakō; K. waegu), and local fishermen and traders to make their voices heard in the regional geopolitics of the fifteenth century. By focusing on Tsushima's ideological positioning, this article clarifies how the ruling Sō clan manipulated the island's representation by shifting its identity between "frontier" (J. kyōkai) and "borderland" (J. henkyō), a subtle differentiation not often discussed. As Kimura Naoya aptly points out, Tsushima/Taema-do is "situated at the periphery (J. shühen), and thus able to be perceived as a borderland according to changing historical circumstances." 8 This article takes an extra step to elucidate this conceptual differentiation by introducing insights from the study of littoral areas in global history that holds the potential for further enriching our understanding of Tsushima/Taema-do as a maritime frontier/border(is)land. This analytical lens transcends not just physical and metaphysical space but also time as the Sō clan of Tsushima/Taema-do had been in the same position mediating with different powers as dynasties rose and fell in both continental Asia and the Japanese archipelago. Furthermore, analyzing current historiographical approaches surrounding maritime studies is useful in revealing how historians are constructing new narratives based on a medium of water that transcends boundaries demarcating sovereignty, cultural differences, and identity.

This article comprises three sections. First, I shall discuss the geopolitical identity of Tsushima/Taema-do as situated at the peripheries of Chosŏn Korea and Muromachi/Ashikaga Japan - a geographical site that fluctuates with changing geopolitical developments. Next, I explore the discursive space occupied by Tsushima/Taema-do as the borderland of both hegemonic powers emphasizing the autonomy of the local ruling

8 Kimura Naoya, "Tsushima: Tsūkō'bōeki ni okeru sesshoku ryōiki," in Iwanami kōza Nihon rekishi dai 20 ken: Chiiki ron, eds. Ōtsu Tōru, et al. (Tokyo: Iwanami Shoten, 2014), 142. 
clan in handling the foreign relations of the regional powers. By comparing the example of Tsushima/Taema-do with other peripheral islands such as Iki island, this article hopes to evince the nuances behind the conceptualization of Tsushima/Taema-do as a marginal actor. The last section looks at non-state actors, specifically the local population and the pirate community, in articulating their agency by forms of negotiation and violence. In conclusion, I reiterate the need to reconceptualize the island's unique geographical place in history in order to advance our understanding of not just fifteenth century East Asian diplomatic history, but no less importantly, of the geopolitical complexities in the region today.

Historical works that take the perspective from the periphery are situated in a discourse that often challenges the privileging of the metropole or the center of power. By evoking the term "periphery," Kimura suggests that Tsushima historically served as the site where diversity was once celebrated as it accommodated different nationalities and cultures sharing a common space. ${ }^{9}$ This presents a stark juxtaposition to today's controversies surrounding disputed territories as his narrative reveals an attempt to trace the historical origins of such conceptualization of diplomatic relations to the nineteenth century emergence of the modern nation-states paradigm that precipitated future international conflict by creating a zerosum game over border demarcation.

Likewise, anthropology and cultural studies look at the "periphery" in a context that differentiates itself from the center with a strong suggestion of a subaltern, postcolonial texture that reacts against the WesternEuropean-centric perspective. ${ }^{10}$ More famously, political scientist Immanuel Wallerstein examines the concept of "periphery" in terms of economic production, defining it as a geographical space "wherein produc-

9 Kimura, "Tsushima," 142.

10 Dina Iordanova, David Martin-Jones, and Belen Vidal (eds.), Cinema at the Periphery (Detroit: Wayne State University Press, 2010), 1-20; Ignacio López-Calvo (ed.), One World Periphery Reads the Other: Knowing the 'Oriental' in the Americas and the Iberian Peninsula (Newcastle: Cambridge Scholars, 2012), 1-18. 
tion is primarily of lower ranking goods (that is, goods whose labor is less well rewarded) but which is an integral part of the overall system of the division of labor," or in opposition to the extension of centralized state power. ${ }^{11}$ These examples present multifaceted definitions of "periphery," sharing a crucial trope of requiring a center that stands in either a different or opposing position relative to the subject.

Whereas the concept of "frontier," due to its intellectual origins of American settler colonists expanding the national territory during the nineteenth century, scholars have noted a much-nuanced implication in explaining imperial tendencies. ${ }^{12}$ Tsushima/Taema-do too, had witnessed episodes of violence in the form of state aggression and endeavors of piracy, revealing the anxieties faced by the state authorities and the local populations. ${ }^{13}$ This is not to emphasize the image of lawlessness or statelessness in the island, but rather, the concept of a "frontier" best describes the fluid nature of diplomacy that the people of Tsushima/Taema-doincluding the local population and the domain authority - engaged in to ensure the island's relevance and survival despite being sandwiched between larger hegemonic powers.

On the other hand, "borderland" alludes to a discernment of some form of demarcation surrounding the subject. Similar to the concepts of "frontier" and "periphery," "borderland" too implies a reference point that is positioned at a considerable distance from the subject. Political scientists have defined borderlands as special geographical spaces with unique rela-

11 Immanuel Wallerstein, The Modern World-System, Volume 1 (New York: Academic Press, 1974), 302.

12 For a succinct historiography of borderland studies, see Pekka Hämäläinen and Samuel Truett, “On Borderlands," Journal of American History 98, no. 2 (September 2011): 338-61.

13 Jeremy Adelman and Stephen Aron, "From Borderlands to Borders: Empires, Nation-States, and the Peoples in between in North American History," American Historical Review 104, no. 3 (June 1999): 814-41; Manan Ahmed, "Adam's Mirror: The Frontier in the Imperial Imagination," Economic \& Political Weekly 46, no. 13 (March 2011): 60-65. 
tionship systems which also served as "sites and symbols of power." 14 From their observations, conceptualization of a region is not just based on geographical distance, but also cultural and ideological differences that account for the spatial gap between the borderland and the metropole. The self-identity of the subject in the overlapping spheres of influence is thus crucial in differentiating between frontier and borderland-the former privileges the autonomy of the subject as empowered by the fluidity of identity, while the latter suggests a loose association with a selected political center that is often characterized as a weakening of centralized authority. Just as how Adelman and Aron define borderland as places marked by "power politics of territorial hegemony," 15 Tsushima/Taemado is indeed at the epicenter of a messy entwinement of early modern East Asian geopolitics involving pirates, the Sō clan, the Ashikaga bakufu, and the Chosŏn court.

In the historiography of international relations in fifteenth century East Asia, historians have come a long way in shifting the conventional vantage point from that of the major powers to those overlooked by a macroscopic overview. One important development was the recalibrating of the historians' lens by rejecting a primarily land-biased approach in favor of a maritime perspective. Moving away from state-centered subjects, historians have shifted the spotlight onto non-state entities such as the "sea lords" of the Seto Inland Sea, ${ }^{16}$ and religious missionaries who played a

14 Oscar J. Martinez, "The Dynamics of Border Interaction, New Approaches to Border Analysis," in Global Boundaries: World Boundaries, Volume 1, ed. Clive H. Schofield (London: Routledge, 1994), 1-15; Ivo D. Duchacek, "International Competence of Subnational Governments: Borderlands and Beyond," in Across Borders: Transborder Interaction in Comparted Perspective, ed. O.J. Martinez (El Paso: Texas Western Press, 1986), 11-28; Hastings Donnan and Thomas Wilson, Borders: Frontiers of Identity, Nation and State (Oxford: Berg, 2000).

15 Adelman and Aron, "From Borderlands," 815.

16 Amino Yoshihiko, Nihon chūsei no hinōgyōmin to Tennō (Tokyo: Iwanami Shoten, 1984), 27-31; Murai Shōsuke, Nihon chūsei kyōkai shiron (Tokyo: Iwanami Shoten, 2013), 35; Peter D. Shapinsky, Lords of the Sea: Pirates, Violence, and 
vital role in maintaining foreign relations and cultural exchanges. ${ }^{17}$ In a similar vein, this article emphasizes the need to engage non-state historical actors and to take a different historical vantage point of privileging non-land entities in understanding diplomatic history especially in an age when written trails were scarce and often in the restricted domains of state or state-related agents.

Inspired by these historical trends, this article highlights the need to consider the geographical and ideological space negotiated by the island over time as it carved out its distinctive position in fifteenth century East Asian geopolitics. Evoking Bashford's concept of "terraqueous history" where the "'terraqueous' had an expansive early modern meaning, signaling not just land and sea, but the transforming matter that constantly connected them: atmospheres, vapors, airs, and waters," 18 I shall attempt to highlight the connections of human activities on both land and sea as seen in the interactions between sea-based pirates and the land-based state authorities of both Korea and Japan. Unlike Robert Ingels Hellyer who draws parallels between the sea lords of the Seto Inland Sea and the ruling Sō clan of Tsushima, ${ }^{19}$ this article highlights that Tsushima/Taema-do presents a unique case study where pirates exhibited the same fluidity of identity assertion in their dealings with state authorities, coopting and resisting state influences according to their personal interests, but were significantly less powerful than their Seto counterparts.

Commerce in Late Medieval Japan (Ann Arbor: Center for Japanese Studies, University of Michigan, 2014), 13.

17 Itō Kōji, "Chūsei kōki no Rinzaishū Genjūha to gaikōryū," Shigaku zasshi 108, no. 4 (1998): 465-500; Osa Masanori, "Keitetsu Genso ni tsuite-Gaikō sō no shutsuji to hōkei," Chōsen gakuhō 29 (1963): 135-47.

18 Alison Bashford, “Terraqueous Histories," Historical Journal 60, no. 2 (February 2017): 255.

19 Robert Ingels Hellyer, "Poor but Not Pirates: The Tsushima Domain and Foreign Relations in Early Modern Japan," in Elusive Pirates, Pervasive Smugglers: Violence and Clandestine Trade in the Greater China Seas, ed. Robert J. Antony (Hong Kong: Hong Kong University Press, 2010), 119. 


\section{Identity as the Frontier: (Re)Incorporating Tsushima/Taema-do into the Confucian Order}

Unlike existing studies on Ezochi (today's Hokkaido) and the Ryukyu kingdom (today's Okinawa) which epitomize the notion of the frontier in Japanese history, the example of Tsushima/Taema-do reveals a different form of dynamics shaped by a constant tug-of-war between the surrounding hegemonies due to its geopolitical position. Nonetheless, Tsushi$\mathrm{ma} /$ Taema-do was not the only territory known to have contacts with Chosŏn Korea. In 1438, clan leader Sō Sadamori requested visiting Chosŏn envoy I Ei to promise that the Chosŏn court would not grant audience to envoys without the access permit, specifying envoys from Kyushu, Satsuma province, and Iwami province. ${ }^{20}$ This suggested precedence of such instances. For example, the ruling Sufu clan of Iwami province worked closely with the Sō clan in obtaining permission to trade with the Koreans and only relinquished trading rights in the late 1470s due to the Onin War and the subsequent ensuing chaos on the main islands. ${ }^{21}$ As for Iki island and the Gotō islands, which lie about $50 \mathrm{~km}$ and $130 \mathrm{~km}$ south of Tsushima respectively, both shared comparable geopolitical characteristics with Tsushima/Taema-do. In fact, there had been nineteen recorded instances of repatriates involving Iki islanders since the Koryŏ period. ${ }^{22}$ Furthermore, the Chosŏn court maintained a direct line of contact with the provincial heads (J. shugo) of Iki island and the Gotō islands in negotiating the repatriation of castaways. ${ }^{23}$ The Gotō islands also maintained a

20 CWS, Sejong sillok, Sejong 20/9/18 [1438/10/6].

21 Seki Shūichi, Chūsei Nitchō kaiikishi no kenkyū (Tokyo: Yoshikawa Kōbunkan, 2007), 169.

22 Seki, Chüsei, 194.

23 Shugo was a political position developed since the Kamakura period that allowed the various warlords to manage their holdings as its top military commander and administrative officer. In 1443, after pirates from Iki and Tsushima had raided a Chosŏn tribute ship off the coast of Jeju island Sō Sadamori volunteered to negotiate for the return of the Korean captives but Iki officials handled the repatriation by 
strong connection with the Chinese Ming court as seen in maps that depict the islands about half the size of Kyushu. ${ }^{24}$ However, the different geopolitical situation in these peripheral islands meant limited interactions with Chosŏn Korea by the end of the fifteenth century. The unification of Iki island under the Kyushu-based Hata clan in 1472 ended IkiKorean interactions as no written records of communications were found since. ${ }^{25}$ For the Goto islands, the Uku clan sought to be co-opted into, not challenge, the existing Sō trading network with Chosŏn Korea. ${ }^{26}$ Hence, though these entities maintained connections with the Chosón court, they were deeply entwined with the politics of the bakufu and thus none enjoyed the same level of autonomy as the Sō clan.

Korean connections could be traced to as early as the sixth century when the Silla court employed the islanders as middlemen for official dealings with the Yamato administration, revealing the early frontier nature of the island's geopolitical position. ${ }^{27}$ The notion of a frontier presents a paradigm that outlines a state of flux where multiple centers are able to exert their respective influences, albeit to a varying degree, over the same subject. Resembling this model is the geopolitics of pre-colonial Southeast Asia described by O.W. Wolters as a paradigm of overlapping mandala or circles of kings. Wolters notes that mandala "represented a particular and often unstable political situation in a vaguely definable geographical area without fixed boundaries and where smaller centers

themselves. See CWS, Sejong sillok, Sejong 28/9/9 [1446/9/29]. For the Gotō islands, the Uku clan received the access permit and traded actively by sending one or two ships annually. See CWS, Seongjong sillok, Seongjong 5/12/1 [1475/1/8].

24 Seki, Chūsei, 193.

25 Hata Yasushi, the castle lord of Kami-Matsuura Kishitake castle, invaded Iki and obliterated four of the five clans (Shisa, Sashi, Yobuko, and Kamouchi) controlling the island. The remaining Shiotsuru clan fled Iki and sought protection under the Sō clan of Tsushima. See Seki, Chūsei, 200.

26 Seki, Chūsei, 205.

27 Seo Youngkyo, "Silla Waeguk sai kyŏnggyein," Hangdo Busan 35 (August 2018): 157-92. 
tended to look in all directions for security" which "would expand and contract in concertina-like fashion." 28 This is analogous to the East Asian region, as Robinson describes Tsushima/Taema-do as the site "where 'dual but unequal state power' mixed, where the royal gaze and the imperial and shogunal gazes mingled." 29

Although the official family genealogy of the Sō clan traced its origins to the famous Heian general Taira no Tomomori $(1152-85),{ }^{30}$ the leader of the Sō family was also a longtime ally and vassal of the royal courts of Korea. The Sō clan had been trading directly with the Korean court since the Koryŏ period as official relations were established by the fourth deputy land steward (J. jitōdai) Sō Tsuneshige 宗経茂 (?-1370/1372) in 1368. Believed to be the earliest written record ever found pertaining to the Sō clan's transactions with Korea, the court entry for the fourteenth day of the eleventh month of 1368 in the Koryǒsa [History of Koryŏ] states that "Manho Tsuneshige sent an envoy to the Koryo court and was given 1,000 koku of rice." 31 Tsuneshige was conferred the Korean official post of Manho, suggesting that he might have pledged his allegiance to the Koryŏ king. Besides, as Chŏng Da-Hum highlights that the Chosŏn court sent a particular type of royal envoy called Kyŏngch'agwan to Tsushima, this was markedly different from the more well-known special envoys known as Tongsinsa who were sent on foreign missions to the bakufu-

28 O.W. Wolters, History, Culture, and Region in Southeast Asian Perspectives (Ithaca: Southeast Asia Publications, Southeast Asia Program, Cornell University, 1999), 27-28.

29 Kenneth R. Robinson, “An Island's Place in History: Tsushima in Japan and in Chosŏn, 1392-1592,” Korean Studies 30 (January 2006): 43.

30 Despite the publication of Sōshi kafu [Genealogy of Sō clan] in 1686, Japanese historians have noted its historical discrepancies and inaccuracies especially of the lineage before the Kamakura period. Nonetheless, see especially Osa Setsuko, Chūsei Nitchō kankei to Tsushima (Tokyo: Yoshikawa Kōbunkan, 1987), 3-35; Tsuruta, Tsushima, 5-7.

31 As quoted in Osa, Chüsei, 40. 
Kyŏngch'agwan were sent specifically to local provinces. ${ }^{32}$ This revealed the special yet unequal relationship between the Chosŏn court and Tsushima, just as how Ming China dispatched a special group of envoys known as Qinchaiguan to its tributary states. ${ }^{33}$

Tsushima's relationship with the Ashikaga bakufu was anything but stable. ${ }^{34}$ Like other regions of the Japanese archipelago in the early years of the fifteenth century, political instability plagued Kyushu as different ruling clans-Shōni, Ōuchi, and Shibukawa-competed for dominance. This prompted internal strife within the Sō clan as the Ni'i 仁位 branch, based in Tsushima, rebelled against its clan leader Sō Sadashige 宗貞茂 (?-1418). Sadashige, who had just wrestled control as the head of the clan in 1398 and was based in Kyushu. Though Sadashige eventually pacified the enemies within by the winter of 1401, different factions on the island periodically challenged the power of the Sō clan as explored in the later sections of the article. Nonetheless, the Sō clan enjoyed much political maneuverability and managed to send seven emissaries to Korea during this upheaval. ${ }^{35}$

An interesting observation of how overlapping authorities exerted their influence over Tsushima/Taema-do is the issuance of fishing and travel rights. Institutionalized border control was also practiced in the southern

32 Chŏng Daham, “Chosŏnch'ogi yain'gwa Taema-doe Taehan pŏlli pŏnbyŏng inshigŭi hyŏngsŏnggwa Kyŏngch'agwanŭi pagyŏn," Tongbanghakchi 141 (March 2008): 228-29; Kim Inhyun, "Joseon Tongsinsa wa Daema-do ui gwangye," Ilbon-eo gyoyuk 79 (March 2017): 131-48. Manho, originally a military rank in the Mongol army, was used to refer to a general in command of a few thousand soldiers in the Korean army. The succeeding Chosŏn court would later adopt this term in referring to Japanese who were conferred an official rank in the Korean administration.

33 Chŏng Daham, “Making Chosŏn’s Own Tributaries: Dynamics between the Mingcentered World Order and a Chosŏn-centered Regional Order in the East Asian Periphery," International Journal of Korean History 15, no. 1 (February 2015): 47.

34 For more details of the early history of the Sō clan, see Nagatome Hisae (ed.), Tsushima kokushi (Tsushima-shi: "Tsushima kokushi”" Kankō Iinkai, 2009), 43-44.

35 Araki, Chüsei, 28-29. 
boundaries of Ryukyu-Satsuma where there were different variants of the Töjin shōmon [Certificate for foreigners] system to allow flexibility for authorities from the Ryukyu kingdom and Satsuma domain in creating the image as "the border of Japan." ${ }^{36}$ A comprehensive system of travel permits was initiated by the Sō clan after the 1419 invasion when the ninth head of the Sō clan, Sō Sadamori 宗貞盛 (1385-1452) had come of age and began to consolidate his authority over the island. In the aftermath of the invasion, the Chosŏn court empowered other western Japanese warlords, including the Kyushu Deputy (J. tandai), Shimazu clan of Satsuma, Ōtomo clan of Bingo, and others from the Matsuura area, by giving them the power to issue permits to Japanese seeking trade. ${ }^{37}$ At the same time, another powerful family based in Tsushima, the Sōda 早田 clan, a wealthy landholding clan involved in both piracy and diplomatic trading, also aggressively courted the favor of the Chosŏn court. Eventually in 1438, the Chosŏn court awarded the exclusive rights to issue travel and fishing permits to Sō Sadamori. ${ }^{38}$ This culminated in the signing of the Treaty of 1445 (K. Gyehae Choyak, J. Kakitsu Joyaku) which officially

36 Watanabe Miki, “"The Border of Japan’ for Chinese Arrivals in Nagasaki, Satsuma, and Ryukyu," Itinerario 37, no. 3 (December 2013): 36.

37 Kenneth R. Robinson, "From Raiders to Traders: Border Security and Border Control in Early Chosŏn, 1392-1450," Korean Studies 16 (1992): 106; James B. Lewis, Frontier Contact Between Chosŏn Korea and Tokugawa (Hoboken: Taylor \& Francis Ltd, 2003), 20.

38 As a way to monitor trading volumes, trading permits in the form of a private copper seal or stamp were issued to travelers from Japan by the Chosŏn court in 1418 . However, with the appearance of forgeries, the Sō clan adopted the Chosŏn special passage permits (K. munin, J. bun'in) system and issued its own special passage permits to traders from Tsushima. It had started unofficially in 1435 but with the agreement signed between King Sejong and Sadamori in 1438, the Sō clan became the only recognized authority to issue such trading permits to Japanese traders. See Kang Etusko Haejin, Diplomacy and Ideology in Japanese-Korean Relations: From the Fifteenth to the Eighteenth Century (New York: St. Martin's Press, 1997), 67-68; Sin Sukchu, Haedong Jegukgi, trans. Tanaka Takeo (1471; Tokyo: Iwanami Shoten, 1991), 129-31; Robinson, "From Raiders," 107. 
established a tributary relationship between Tsushima and Korealegitimizing the political authority of the Sō clan and strengthened its economic status on the island. ${ }^{39}$

In fact, several of the pirate chiefs based in the coastal bays around the island, including the Sōda clan, had been conferred official posts by the Chosŏn court and given trading permits (K. tosŏ, J. tosho) to trade with the Koreans. ${ }^{40}$ The most influential was Sōda Saemontarō 早田左衛門太 郎 (?-1428), who received the rank of Manho and was at one time the main power broker of the island. ${ }^{41}$ Coopting the pirates into its trading network was a strategic maneuver not only to minimize future attacks but also to employ them as agents to monitor the island. This effectively placed Taema-do under the surveillance of the Chosŏn court, establishing some form, albeit limited, of jurisdictional sovereignty over the island. ${ }^{42}$ By conducting trade and conferring official posts, such practices also served as a form of maritime defense. Hence, the Chosŏn court perceived the space encompassing Taema-do and its surrounding seas as "a zonal boundary," serving as a peripheral buffer that could be controlled. ${ }^{43}$

From 1434 to 1459, Sadamori began using the term Tsushima-kuni interchangeably with the more familiar term, Tsushima-tō, in official correspondence. ${ }^{44}$ As Osa Setsuko argues, this revealed the ambitions of the

39 On details of the Kakitsu Articles, see Kang, Diplomacy, 67-68.

40 Three of the five pirate chiefs were conferred the Japanese rank of Gogun which is a military rank in the Chosŏn court equivalent to the Senior Fourth Rank of the Five Guards (K. Owijong sap'um). See Sin, Haedong, 200-21.

41 The untimely death of the eighth head of the Sō clan, Sō Sadashige, in 1418 was a major contributing factor to the Chosŏn offensive a year later. Chosŏn officials were disappointed that a young and inexperienced Sō Sadamori succeeded Sadashige. Hence, during that period, Chosŏn officials considered Sōda as the most powerful figure of the island. See Kang, Diplomacy, 58; Jeong Yeonghyeon, "Tonghaeanŭi waeguwa Ssŭshima Chojŏnssi," Han'guk minjok munhwa 67 (May 2018): 199-233.

42 Robinson, "An Island's," 42.

43 Robinson, "An Island's," 44.

44 Yamaguchi Takamasa, "Tsushima Shugo," in Nanbokucho-ki Kyushu-shugo no 
clan to upgrade the status of Tsushima from that of a fief as a vassal's holding under the sponsorship of the Shōni clan, to that of a province (J. ryōgoku) that was on par with other provinces based on the Ritsuryō system. ${ }^{45}$ Furthermore, Sadamori sought to monopolize diplomacy with Korea which served the dual purpose of solidifying the Sō clan's autonomy and to gain recognition of its power in the region. ${ }^{46}$ Hence relations with Korea served not simply just as a means for economic survival but was a tool for establishing political legitimacy as well.

How then did the bakufu react to such developments, especially on the tributary relationship between the Chosŏn court and the Sō clan? This remained a mystery but given the frequent travelling by Japanese and Korean traders and even Korean envoys sent to the bakufu, it would not come as a surprise if the bakufu knew about it. However, the silence and inaction of the bakufu suggests its implicit recognition of the status quo. In noting the nature of diplomacy conducted at that time, Kang points out that the "ambiguity of balance between authority and power was a strong tradition in Japan." 47 I would supplement that the position of Tsushima at the frontier, where overlapping authorities from different political centers merged, was a key factor in accommodating such ambiguities in the first place. Occupying "a zone of ambiguous boundary qualities," Tsushima was thus empowered with an exceptional degree of autonomy in dealing with foreign powers. ${ }^{48}$

Kenkyu, ed. Yamaguchi Takamasa (Tokyo: Bunken Publishing Company, 1989), 565-98.

45 Osa Setsuko, “Tsushima-tō Sōshi seikei no seiritsu,” Nihon rekishi 208 (1965): 4253.

46 Osa Setsuko, "Tsushima Sōshi ryōgoku shihai no hatten to Chōsen kankei shokeneki," Journal of the Academic Association of Koreanology in Japan 39/40 (1966): 182-209.

47 Kang, Diplomacy, 20.

48 Ronald P. Toby, State and Diplomacy in Early Modern Japan: Asia in the Development of the Tokugawa Bakufu (Princeton: Princeton University Press, 1984), xx. 


\section{Identity as a Border(is)land: (Re)Claiming Tsushima/Taema-do in Hegemonic Narratives}

Despite Tsushima/Taema-do's closer proximity to Korean shores, the greatest irony was that Chosŏn officials actually believed that it was "due to its inaccessible location" that resulted in the Japanese occupation. ${ }^{49}$ Nonetheless the island occupies a geographical space that is the furthest from either the Chosŏn court in Hanyang or the bakufu in Kyoto. This section argues how this position at the borderland, where Tsushima/Taema-do is conceived as a separate entity detached from the centralized political institutions, empowered the island to negotiate its dealings with the respective political centers. As Robinson deftly puts it, "it was less the island's position along the sea route to Chosonn and more the Tsushima shugo's political distance from the shogunal view that allowed the shugo and Korean officials to cooperate in the control of Japanese access and to situate Tsushima in an ambiguous state." 50

The Koreans' worldview was ordered strictly along Confucian ideas and Taema-do was inhabited by the barbaric, uncivilized Japanese. In the various records of the Chosŏn court and travelogues of the Chosŏn embassies to Japan, Korean diarists used the term "waeguk" or "waein" to refer to Japan or the Japanese, which meant "outlandish country" and "strange, peculiar people" respectively. ${ }^{51}$ In fact, retired King T'aejong pointed out that Korean possession of Taema-do was preserved in Korean historical records as "the island had been subordinate to Kyerim, a sobri-

49 CWS, Sejong sillok, Sejong 2/6/9 [1419/7/1].

50 Kenneth R. Robinson, "The Tsushima Governor and Regulation of Japanese Access to Chosŏn in the Fifteenth and Sixteenth Centuries," Korean Studies 20 (1996): 42.

51 Lee Jeongmi, "Chosŏn Korea as Sojunghwa, the Small Central Civilization: Sadae kyorin Policy and Relations with Ming/Qing China and Tokugawa Japan in the Seventeenth Century," International Christian University Asia Culture Research 36 (March 2010): 307. 
quet for the Silla government." 52 The Korean court thus maintained the impression that Taema-do was previously Korean territory but unfortunately fell into the hands of the "evil banditry," the pirates. ${ }^{53}$ An authoritative Korean publication Tongguk yŏji sŭngnam [Augmented Survey of the Geography of Korea], published in 1481, indeed included Taema-do as part of Kyerim. ${ }^{54}$ This might explain T'aejong's decision to attack Tsushima later in 1419, despite the opposition of the reigning ruler, King Sejong. ${ }^{55}$ Furthermore, elite Korean literati shared a common historical understanding of the island by regarding the Japanese who lived on Taema-do as dangerous barbarians who had invaded and occupied Korean territory. ${ }^{56}$

In the authoritative 1487 and 1499 editions of the Tongguk yöji sŭngnam [New Augmented Survey of the Geography of Korea], Taema-do was listed as part of Kyŏngsang province. ${ }^{57}$ In 1443, Sin Sukchu, a Chosŏn envoy who travelled to Kyoto, meticulously mapped Tsushima by detailing the eighty-two bays that encircle the island in his travel diary. ${ }^{58}$ Rather than use Japanese nomenclature to refer to the places like he did for the islands in the Seto Inland Sea, Sin used kanji characters that correspond with the kun-reading of the Japanese characters, e.g., Hitakatsu bay 比田勝浦 is written as 皮多加地浦. This revealed his perception of the island as a non-Japanese entity as compared to the other regions he had

52 CWS, Sejong sillok, Sejong 2/7/17 [1419/8/8].

53 CWS, Chŏngsong sillok, Chŏngsong 1/7/1 [1399/8/2].

54 Kang, Diplomacy, 59.

55 Seki, Tsushima, 35; Tanaka Takeo, Wakō: Umi no rekishi (Tokyo: Kyōikusha Shuppan Sābisu, 1982), 74.

56 Don Baker, "Confucianism and Civilization: Tasan Chŏng Yagyong's Views of Japan, the Ryūkyūs, and Tsushima," Korean Studies 40 (January 2016): 48.

57 Kenneth R. Robinson, "Maps in Extant Volumes of the 1487 Tongguk yŏji sŭngnam and the 1499 Tongguk yŏji sŭngnam, and in Sinjŭng Tongguk yŏji sŭngnam," International Christian University Asia Culture Research 36 (March 2010): 263, 269.

58 Sin, Haedong, 388-89. 
visited.

The differentiation of Taema-do from the other provinces ruled by the bakufu was apparent in the Chosŏn court's conduct of diplomatic affairs. Robinson points out that the governor of Taema-do and his Special Envoy representative was ranked third, in the four-tier hierarchy of Chosǒn court reception, below the first-ranked Shogun and the Ryukyuan king, and the second-ranked bakufu officials. ${ }^{59}$ This reflected not just the diplomatic significance of the island in the eyes of the Chosón court but also an official conceptualization of a separate identity of the island that differentiated its inhabitants from the rest of bakufu-controlled Japan.

As a Japanese borderland, Tsushima was no stranger to being attacked by the Korean military as both the Koryŏ and Chosŏn courts had previously sent troops in retaliation to the pirates' raids of the southern coasts. ${ }^{60}$ After each expedition, it remains a mystery why the Korean navy was not permanently stationed on the island to prevent further transgression by the pirates. In the 1419 Kihae Eastern Expedition (K. Kihae tongjŏng) led by Chosŏn navy admiral Yi Chongmu (1360-1425), a total of 17,285 soldiers on 227 ships were sent to attack Tsushima. ${ }^{61}$ To the Chosŏn court, the military operation was a success in subduing the pirates as a certain degree of authority was imposed on the island. Although the

59 Kenneth R. Robinson, "Centering the King of Chosŏn: Aspects of Korean Maritime Diplomacy, 1392-1592," Journal of Asian Studies 59, no. 1 (February 2000): 111; Kenneth R. Robinson, "Organizing Japanese and Jurchens in Tribute Systems in Early Chosŏn Korea," Journal of East Asian Studies 13, no. 1 (May-August 2013): 356.

60 During the Koryŏ dynasty (1223-1391), there were a total of 311 pirate raids, and 155 times in the succeeding Chosŏn years before the 1419 attack. The last Koryŏled expedition was in 1389. See Tanaka, Wakō, 200-7.

61 This was also known as the Ōei Invasion (J. Ōei no gaikō). When the Korean navy landed on the beaches of Tsushima, they were met with little or no resistance. They captured 129 vessels, of which half were destroyed, burnt down 1,939 households, executed 104 people, and enslaved twenty-one prisoners. They were also able to rescue 131 Ming Chinese captives. See CWS, Sejong sillok, Sejong 2/6/20 [1419/7/12]. 
navy's withdrawal came after the advice of the head of the Sō clan, it coincided with the aftermath of the battle of Nukadake 糠獄 where Japanese sources recorded a casualty of 223 Japanese and over 2,500 Koreans. In view of these developments, Sadamori wrote to the Korean navy, under the guise of an impending typhoon, and advised a retreat to avoid further casualties. ${ }^{62}$ Another possible reason for the Korean retreat despite no indication of any Japanese reinforcements is that the Chosŏn court recognized the position of Taema-do as a Japanese borderland where a permanent Korean military presence would destabilize the balance of power in the region.

As pointed out earlier, King Sejong never supported the idea of attacking Taema-do. Rather, it was T'aejong who suggested mobilizing the navy against Taema-do. In the end, it was King Sejong who, after the navy had retreated from Taema-do, proposed the capitulation of the Sō clan and the resettlement of the island's entire population to the Korean peninsula. ${ }^{63}$ Instead, Sō Sadamori dispatched an envoy named Jiō Kaito to Hanyang who relayed his counter-proposal as follows,

"The land of Tsushima Island is barren, and life is truly difficult. I seek permission to send islanders to be stationed on islands such as Garasan [today's Kŏje-do] so as to guard the islands from without. I entrust that your esteemed country will allow the people of Tsushima to enter the southern islands of Chosŏn Korea and till the fields freely; you could collect land taxes from them, and allocate to us at your will. I fear that my relatives are looking for a chance to seize the seat of shugo, and so I am unable to leave the island." 64

Rather than submitting to the idea of transplanting the island's popula-

62 Tanaka, Wakō, 73-77.

63 CWS, Sejong sillok, Sejong 2/7/29 [1418/8/20]; Sejong 2/9/20 [1419/10/9].

64 CWS, Sejong sillok, Sejong 2/Intercalary 1/10 [1420/1/24]. 
tion to the direct control of the Chosŏn court, Sadamori recommended sending them to the outlying southern islands - on the periphery of Chosŏn's direct authority-where room for negotiation and maneuvering control of subsequent settlement might be possible. Refuting Murai's assertion that Jito was not sent by Sadamori, Araki argues that the counterproposal was actually in line with the long-term political goal of the Sō c lan as predecessors had attempted to claim control over the outlying southern islands from the Chosonn court. ${ }^{65}$ Besides, the last sentence of the excerpt revealed the fragile position Sadamori was in and th us this counter-proposal was possibly his first move at cementing his authority as the rightful leader of the Sō clan and Tsushima. Furthermore, the report continued,

"If Tsushima is to be given a county name and accorded with the special passage permit, I will serve as a member of your court. Of the thirty pirate ships that had raided Toduŭm Cape, sixteen ships were destroyed in battle, and the remaining fourteen ships were returned, of which seven ships belonged to the people of Iki Province, who had returned to the island. The other seven ships belonged to our islanders. Their ship captain(s) died in battle, and only the sailors returned. I have arrested the ringleaders, one from each ship, together with their wives and sons. Their possessions and the ships have been confiscated, and I await upon your instructions to deal with them immediately."

Not only did Sadamori divulge information of the pirates' whereabouts and offer to subject those perpetrators to the laws of the Chosŏn court, he also offered the control of Tsushima to the Chosŏn King as part of the settlement deal. In its reply less than two weeks later, the Chosŏn court instructed Sadamori to report directly to the governor of Kyŏngsang Prov-

65 Araki, Chūsei, 55.

66 CWS, Sejong sillok, Sejong 2/Intercalary 1/10 [1420/1/24]. 
ince, differing from earlier correspondence with the Ministry of Rites as this new set of instructions was in line with the protocol for administering local provinces. From the Chosonn court's point of view, Sadamori had accepted to transfer sovereignty of Tsushima to the Chosŏn state-but more importantly, Sadamori successfully received the special passage permit to conduct trade with Korea. ${ }^{67}$

However, this subordinate relationship was an unrequited affair. A Chosŏn envoy Song Hŭigyŏng, en route to the Ashikaga court, made a stopover at Tsushima and brought up the issue of the island's incorporation into the Chosŏn state in a discussion with Sōda Saemontarō, an influential power broker on Tsushima who was also a pirate and merchant. Sōda responded: "Tsushima belonged to the Shōni family, and I would gladly 'fight a hundred battles and die a hundred times before giving the island to the king of Chosŏn!" "68 Moreover, Song recorded in his diary that a Hakata merchant mentioned that the Shōni clan could assemble a fleet of over 300 ships in a day's notice to raid the southern coast - a clear warning to the Chosorn officials that the Japanese domains were willing to take up arms to resist a second offensive. ${ }^{69}$ Upon learning the threat, the Chosŏn court decided to send naval ships to Kŏje-do to blockade trade and fishing activities with Tsushima fishermen, and even detained envoys and merchants from Tsushima. ${ }^{70}$ The message was clear: the Sō clan and its affiliates had "betrayed the goodwill of the court" and only by "expressing sincere remorse of their insolent actions" would the "blockade be lifted." 71 This was calling for Sadamori to fulfil his side of the deal by "surrendering the island for its incorporation into Chosŏn Korea."72

67 CWS, Sejong sillok, Sejong 2/Intercalary 1/23 [1420/3/7].

68 Song Hŭigyŏng, Nosongdang Ilbon haengnok, ed. Murai Shōsuke (1424; Tokyo: Iwanami Shoten, 1987), 198.

69 Song, Nosongdang, 230; CWS, Sejong sillok, Sejong 2/10/8 [1420/11/13].

70 CWS, Sejong sillok, Sejong 2/10/21 [1420/11/26]; Sejong 2/10/22 [1420/11/27]; Sejong 2/10/27 [1420/12/2].

71 CWS, Sejong sillok, Sejong 2/11/3 [1420/12/7].

72 CWS, Sejong sillok, Sejong 2/11/15 [1420/12/19]. 
In response, Sadamori sent an envoy named Ku Rian to defuse the impending diplomatic crisis. As written in a 1421 report from the Ministry of Rites,

"Sadamori was not implicated in the pirate raids, for such acts should not be tolerated and are to be condemned. But thirteen of our trading ships which were not involved in the raids were currently detained. If the court is willing to release them, the Sō clan will take measures to eradicate piracy in the surrounding waters and restore friendly relations with the court in the long term. Sadamori often mentioned that when his predecessor was alive, the King lavished much generosity upon him; and upon his death, the King even dispatched envoys to send his condolences. Such was the magnanimity of the King." 73

In making his case, $\mathrm{Ku}$ appealed to both legal reasoning in disputing the unjustified detainment of the trading ships, as well as to precedence when the Chosŏn court had favorably treated the rulers of Tsushima. Among Ku's requests, the release of a Chosŏn-Japanese government official named P'yŏng Tochŏn was specifically addressed in the report. ${ }^{74}$

First appearing in the records as an envoy sent by Sadashige in 1407, P'yŏng was possibly the most important individual in Tsushima-Korea relations in the early fifteenth century. ${ }^{75}$ Attaining the position of the rank of junior third grade in the military bureaucracy, P'yŏng, who was not a former pirate, became the highest-ranking Japanese in the Chosŏn

73 CWS, Sejong sillok, Sejong 3/4/7 [1421/5/8].

74 Japanese who had received government posts from the Chosŏn court were known as jushokunin. Most of them, with the exception of P'yŏng, were former pirates. See Matsuo Hiroki, "Chōsen ōchō no Nihonjin kanshi-Taira Dōzen," Ajia yūgaku 177 (2014): 129-36; Tamura Hiroyuki, "Chūsei Nicchō bōeki no mondaitenToku ni Taira Dōzen wo chūshin toshite," Keizai keiei ronsō 13, no. 3 (1978): 1943.

75 CWS, T'aejo sillok, T'aejo 7/3/16 [1407/4/23]. 
court. ${ }^{76}$ Shortly after being rewarded for a successful attack against the pirates in Paengnyŏng-do in the fifth month of 1419, P'yŏng went from one of the most celebrated Japanese in the court to becoming a common enemy accused of being a double-agent: his son was executed, and he was banished to P'yŏngan Province for his remaining years. ${ }^{77}$ Though the exact reasons for P'yŏng's meteorite-like fall from grace remained contested, his dismissal might have been the final trigger as the invasion of Tsushima commenced just days after his son's execution. ${ }^{78}$

Not overlooking the white elephant in the room, the debate proceeded to deal with the delicate issue of the sovereignty of Tsushima/Taema-do. The Ministry of Rites continued,

"Your letter asserted that the claim of Tsushima belonging to Kyŏngsang Province had no historical support and was simply just hearsay. However, this claim was clearly recorded in ancient documents. Besides, one of your envoys Sin Kyeto [Jiō Kaito's Korean alias] had once claimed that the island was originally a place where horses were raised for Chosŏn Korea. Hence all previous reports on the general affairs of the island were submitted to the governor of Kyŏngsang Province and the King. Thus, it is not that Chosŏn covets the island. "79

By referring to the earlier and recent correspondence with Jiō, the Ministry of Rites seemed to be stressing that Chosŏn had no covert malignant intention of coveting the island as its claim was well-supported by historical evidence and was even acknowledged by a representative from the Sō clan. Hence, other than maintaining a physical presence on the island, the

76 CWS, T'aejo sillok, T'aejo 12/10/17 [1412/11/21].

77 CWS, Sejong sillok, Sejong 1/5/24 [1419/6/17]; Sejong 1/6/1 [1419/6/23]; Sejong $8 / 12 / 3$ [1426/12/31].

78 Matsuo, "Chōsen," 133-35.

79 CWS, Sejong sillok, Sejong 3/4/7 [1421/5/8]. 
Chosŏn court seemed to be the de jure sovereign of Tsushima.

However, $\mathrm{Ku}$ offered a witty syllogism in reaching a win-win resolution,

"No one knows if Tsushima belonged to Kyŏngsang Province, so how could Sin make such a preposterous claim? Even if we assume, for the sake of discussion, that our island is subordinate to Kyŏngsang Province, if the people of Tsushima were not appeased appropriately, the reputation of the Chosŏn court would inevitably be lost. Even if our island is not part of Kyŏngsang Province, if the Chosŏn court responded by showing its magnanimity to the population, who would dare challenge or resist submission to your authority? Tsushima is the borderland of Japan. If you attack Tsushima, it is the same as attacking Japan." ${ }^{80}$ [emphasis in italics]

The 1419 invasion took place just months after King Sejong had ascended to the throne, which would have projected a poor image of the new king among the population of the island. People on Tsushima were still struggling to recover from the devastation of the invasion, and thus, as $\mathrm{Ku}$ proposed, if the Chosŏn court refrained from further aggression toward the island, the people would be forever grateful to the court. Besides, another invasion would signal war with the bakufu since Tsushima was located strategically within its sphere of influence. More importantly, by appealing to the ideal moral Confucian leader, Ku hypothetically presented that it would not be impossible that the island would submit to Chosŏn authority in the future. $\mathrm{Ku}$ was not trying to ingratiate himself with the king, but rather to implicitly acknowledge the superior status of King Sejong vis-à-vis Sadamori. In his proposal, Ku projected expectations of how the more powerful member, King Sejong, should performto be generous and accede to the requests of his weaker counterpart. Thus, it might be possible that $\mathrm{Ku}$ recognized the sensitive geopolitical circum-

80 CWS, Sejong sillok, Sejong 3/4/7 [1421/5/8]. 
Table 1. Number of Japanese Trade Envoys Received at the Chosŏn Court $(1401-50)^{81}$

\begin{tabular}{|c|c|c|c|c|c|}
\hline Year & $\begin{array}{l}\text { Name of } \\
\text { monarch }\end{array}$ & $\begin{array}{c}\text { Number of } \\
\text { Japanese en- } \\
\text { voys }\end{array}$ & Year & $\begin{array}{l}\text { Name of } \\
\text { monarch }\end{array}$ & $\begin{array}{c}\text { Number of } \\
\text { Japanese } \\
\text { envoys }\end{array}$ \\
\hline 1401 & \multirow{18}{*}{ T'aejong } & 6 & 1432 & \multirow{18}{*}{ Sejong } & 15 \\
\hline 1402 & & 1 & 1433 & & 9 \\
\hline 1403 & & 2 & 1434 & & 25 \\
\hline 1404 & & 1 & 1435 & & 21 \\
\hline 1405 & & 2 & 1436 & & 22 \\
\hline 1406 & & 6 & 1437 & & 48 \\
\hline 1407 & & 4 & 1438 & & 44 \\
\hline 1408 & & 2 & 1439 & & 46 \\
\hline 1409 & & 2 & 1440 & & 11 \\
\hline 1410 & & 3 & 1441 & & 15 \\
\hline 1411 & & 6 & 1442 & & 34 \\
\hline 1412 & & 9 & 1443 & & 30 \\
\hline 1413 & & 18 & 1444 & & 10 \\
\hline 1414 & & 14 & 1445 & & 7 \\
\hline 1415 & & 14 & 1446 & & 8 \\
\hline 1416 & & 19 & 1447 & & 9 \\
\hline 1417 & & 11 & 1448 & & 4 \\
\hline 1418 & & 14 & 1450 & & 14 \\
\hline 1419 & \multirow{13}{*}{ Sejong } & 14 & & & \\
\hline 1420 & & 6 & & & \\
\hline 1421 & & 6 & & & \\
\hline 1422 & & 9 & & & \\
\hline 1423 & & 18 & & & \\
\hline 1424 & & 6 & & & \\
\hline 1425 & & 5 & & & \\
\hline 1426 & & 9 & & & \\
\hline 1427 & & 8 & & & \\
\hline 1428 & & 24 & & & \\
\hline 1429 & & 11 & & & \\
\hline 1430 & & 25 & & & \\
\hline 1431 & & 17 & & & \\
\hline
\end{tabular}

81 As adapted from Tamura Hiroyuki, Chūsei Nitchō bōeki no kenkyū (Kyoto: Sanwa Shobō, 1967), 175-78, 191-201. 
stances in both Korea and Tsushima, and ingeniously provided a solution honored by the principles of Confucian leadership.

Finally, another supporting piece of evidence can be found by comparing the number of trade envoys allowed into the Chosŏn court during King T'aejong's and King Sejong's reigns (See Table 1). Notwithstanding the trend of increasing trade, King Sejong appeared more receptive in welcoming Japanese envoys even after the end of the conflict. Moreover, trade envoys were not simply engaged in the trading of goods; they too served as important sources of information in diplomacy. ${ }^{82}$ King Sejong was not only more pro-Japanese than his predecessor, he also adopted a reconciliatory approach in his foreign policy, at least in his dealings with the bakufu and Taema-do.

\section{Tsushima/Taema-do on its Own Right: The "Pirates" and the People}

The Woren [sea settlers], in the big ocean southeast of Daifang Commandery [A Chinese colony set up in the northern Korean peninsula], form their communities on the mountainous islands. ... If one crosses 1000 li of ocean, he comes to Duimaguo [Tsushima/Taema-do]. ... It is a desert island. ... The land is very mountainous, steep, and wooded. The roads are as narrow as a deer path. It has some one thousand households and no fertile paddies. They support themselves by eating sea products, and trade with the southern and the northern lands by boat. ${ }^{83}$

The above passage was the first written account of Tsushima, found in

82 See especially Osa, Chüsei, 215-76.

83 Wei Zhi, Vol. 30, 23-24 as quoted in M.S. Seoh, "A Brief Documentary Survey of Japanese Pirate Activities in Korea in the 13th-15th Centuries," Journal of Korean Studies 1, no. 1 (July-December 1969): 26-27. 
the Chinese official history of Wei Zhi [Records of Wei] that was written in the $3^{\text {rd }}$ century CE. The description of the barren landscape was a common observation picked up by writers even a millennium later. In 1487, Chŏng Sŏngkŭn, a member of the Tongsinsa led by Sin Sukchu, wrote in his travel journal,

"The quality of the soil is poor and there are no paddy fields. Everyone ploughs the mountainous fields to get food. As it is banned to cut down forests, it is not possible to get crops by clearing land for agricultural fields. People depend on Japanese arrowroot and bracken roots, or the fishes in the seas and boil them for consumption. Many people were in starvation. In the past, they would raid and plunder our borders (coasts) for subsistence. But the lord of Tsushima island suppressed such activities strictly. Instead the people exclaimed that, 'He is trying to starve all of us to death!""84

Despite the apparent scarcity of arable land on the island, historical records reveal that the population was heavily involved in fishing as well as a flourishing salt production industry. ${ }^{85}$ Sin wrote, "[P]eople live along the coastal bays, a total of eighty-two bays. It takes three days to travel from north to south, half a day to a day from east to west. Mountains and rocks surround the four sides and the people are poor. The people depend

84 Saeki Kōji, Tsushima to kaikyō no chūseishi (Tokyo: Yamakawa Shuppansha, 2008), 24.

85 Whaling was common in Tsushima as whales would swim north up the west side of the Tsushima straits at the break of spring. They would then swim south along the east side of Tsushima straits during autumn. Local fishermen would chase after the whales, cornering them in the bays to hunt them. But Nagatome notes that whaling was not for consumption, but rather for the extraction of their oil as the rest of the body would be disposed somewhere far in the seas. See Nagatome, Tsushima, 56-57. 
on the production of sea salt, fishing, and trade for survival." ${ }^{\prime 66}$ By examining a prose written by a clerk named Kim Hŭn upon his arrival at Tsushima in 1479, I highlight two main themes in his portrayal of the islanders - the lack of culture and material.

"Many of the locals are fisherman. Half of the houses in the village are salt farms. The roofs are not made of tiles but thatched.... small amounts of rice are produced in fields that are not suitable to be ploughed. ... Though people take off their shoes as a form of respect to the elders, they sit irrespective of one's seniority and the fathers do not have much influence. ... They stare intensely in each other's eyes, causing much anger to grow within, then they get rough and violent, and they easily kill each other. ... When the locals get drunk, they let out noises like the birds, and sing like frogs." 87

Noting a typical day on the island, Kim noted the inhabitants' unConfucian demeanor, especially in the disregard of hierarchy which was the cardinal principle in Confucian thinking. Besides, Kim did not hide his disdain of the islanders' uncouth behavior by noting the rowdy behavior in disrupting social order. Furthermore, on the scarcity of material, it was the obvious lack of rice that revealed how precious this food staple was to the island. In fact, rice had been regularly sent from Korea since $1406{ }^{88}$ Researchers have estimated that the wide fluctuations in trade with Korea meant only around 20,000 koku in annual rice production came from Tsushima. This was clearly insufficient for the local population. Rice imports, from both Korea and Japan, had become a necessity for the survival of the island's population. This explains the So clan's swift and prompt response to reach out to the Korean court each time after

86 Sin, Haedong, 194-96.

87 Saeki, Tsushima, 26.

88 Sin, Haedong, 196; Kang, Diplomacy, 58. 
a conflict was settled. ${ }^{89}$ Restoration of trade was thus a matter of survival for the island.

Piracy was undeniably a significant historical force in East Asian history, as seen in how it had (in)directly led to the downfall of the ruling dynasties of Korea and China in the fifteenth century. ${ }^{90}$ As land-based economic activities were severely limited, nautical options such as piracy was one way for the islanders to make ends meet. Besides, as a frontier island situated beyond the reaches of any effective form of terrain-based central jurisdiction, it was no surprise that Tsushima/Taema-do gained the infamous reputation of being a haven for nautical outlaws. Local pirate leaders based in Tsushima/Taema-do were either incorporated into the bureaucracy, ${ }^{91}$ or were imminent threats to the regional powers. ${ }^{92}$ In fact,

89 For example, despite the Sō clan's involvement in the 1510 riots, Hellyer argues the Chosŏn court came to see the Sō leadership as a crucial partner in their fight against piracy, hence restoring trading privileges to them promptly after two years the riots ended. See his Defining Engagement: Japan and Global Contexts, 1640 1868 (Cambridge, MA: Harvard University Press, 2009), 31.

90 Robert J. Antony, "Introduction: The Shadowy World of the Greater China Seas," in Elusive Pirates, Pervasive Smugglers: Violence and Clandestine Trade in the Greater China Seas, ed. Robert J. Antony (Hong Kong: Hong Kong University Press, 2010), 3; Yoshi Saburo Kuno, Japanese Expansion on the Asiatic Continent: A Study in the History of Japan with Special Reference to Her International Relations with China, Korea, and Russia, Volumes 1 and 2 (Berkeley: University of California Press, 1937), 67.

91 One pirate leader, $\mathrm{Na}$ Kaon was mentioned several times in the official Chosŏn archives: he led a fleet of twenty-four vessels to surrender to the Chosŏn court and was appointed as a Manho. His son To Sira, together with his followers, received court appointments too. See CWS, T'aejo sillok, T'aejo 6/2/10 [1397/3/9]; T'aejo sillok, T'aejo 6/4/1 [1397/4/28]; T'aejo sillok, T'aejo 6/4/26 [1397/5/23]; T'aejo sillok, T'aejo 6/4/27 [1397/5/24]; T'aejo sillok, T'aejo 7/2/17 [1398/3/5].

92 From hearsays of pirates wanting to "covet the wealth and riches of Chosŏn Korea" to divulged plans of an impending raid along the Chinese coast, see $C W S$, T'aejong sillok, T'aejong 7/8/11 [1407/9/12]; Sejong sillok, Sejong 1/1/13 [1419/2/7]. Natural calamities on the island such as famines might have led to raids along the Korean coasts. See CWS, Sejong sillok, 1419/5/7 [1419/5/31]; Seki, 
both the Chosŏn court and Japanese authorities recognized the relevance of these mercenaries in local economies and affairs of state diplomacy-it was the ability to manipulate this "rhetoric of piracy as a tool for the delegitimization of opponents and a signifier for the autonomous naval service specialists that they needed to employ in order to engage in both domestic and overseas trade." 93

Hence, the Chosŏn court dealt with piracy cautiously and handled the matter in a pragmatic manner in the belief that the root of such transgression was due to the paucity of the littoral population. ${ }^{94}$ It was also an expression of the court's magnanimity as a Confucian civilization toward a lesser order. This was reflected in the conferring of official titles to these pirate chiefs to coopt them into the official trade networks as sanctioned by the court. However, in the unique case of Sōda Rokurōjirō 早田 六郎次郎 (?-?), son of Sōda Saemontarō, it was through a display of dual identities, both as a state-sanctioned trader and an outlaw pirate. Rokurōjirō was actively involved in the Ryukyu-Tsushima-Korea trade route during the 1420 s and 1430s. ${ }^{95}$ In a memorandum to the Chosŏn court submitted by a Ryukyuan envoy Ka Reikyū, Ka explained to King Sejong that "[i]n the sixth month of the previous year, the pirate chief Rokurōjirō led his merchant fleet to Ryukyu. We used this opportunity and came to Korea together." 96 This reflected a complex relationship between Rokurōjirō and the other state authorities in the region. During the early modern period, piracy was a subjective term that referred to both illicit

Tsushima, 35; Tanaka, Wakō, 74.

93 Shapinsky, Lords, 208-9.

94 For example, King Sejong said to the officials of Kyŏngsang province that "[t]he pirates of Tsushima and Iki [Islands] all rely on Japan for clothes and food. Recently, Japan's roads are blocked due to war. It is possible that [they] will steal like petty thieves from our borders if [they] run out of clothes and food. [Therefore], do not say that there is nothing to worry, and [instead] carefully defend [our borders]." See CWS, Sejong sillok, Sejong 8/3/29 [1426/5/6].

95 Seki, Tsushima, 29.

96 CWS, Sejong sillok, Sejong 13/11/9 [1431/12/13]. 
and licit activities at sea as legitimized by the use of violence for defensive warfare. ${ }^{97}$ Hence, to understand Rokurōjirō's position in the trading relations of early modern East Asia, we need to disengage from our modern understanding of piracy as violent, illegal, and immoral. It is this flexibility of identities that anchored Rokurōjirō's role as an important agent brokering trade relations between the different administrations.

Moreover, at the height of power of the Sōda clan, Saemontarō was able to surpass the Sō clan's authority by collecting taxes from the Japanese traders residing in Chep'o. ${ }^{98}$ However, after his untimely death in the late 1420s, the Sōda clan gradually fell out of favor with the Chosŏn court. Unlike his father who had successfully maintained a higher number of trade envoys than the Sō clan, the decrease in numbers during Rokurōjirō's tenure indicates that he had failed to secure Chosŏn's endorsement (see Table 2). By 1433, the advent and consolidation of power by the Sō clan was complete as Rokurōjirō was recognized by the Chosŏn court as one of the Sō clan's retainers. ${ }^{99}$

In comparing the numbers from both Tables 1 and 2, one realizes that the number of trade envoys do not tally (see Table 3 ). Aside from possible human errors, a plausible explanation is that Japanese outside of the two most powerful clans from the island were also trading with Chosŏn Korea. This corroborates with earlier claims on the engagement of other Japanese clans with the Chosŏn Court in matters ranging from fishing permits to travelling rights. Moreover, the Tsushima population was proactively asserting their agency in different ways, albeit small in scale, to affect changes in their own lives. For example, in the negotiation of fishing rights near the Koch'o island during the 1440s, Sadamori supported his case by arguing that, "[r]ather than wait for death, the Tsushima islanders would rather choose to risk it to fish in Koch'o island. If the Korean officials deem this as illegal and attack them, the islanders might

97 Shapinsky, Lords, 51.

98 CWS, Sejong sillok, Sejong 11/3/22 [1429/4/25].

99 Tamura, Chūsei, 245. 
Table 2. Number of Japanese Trade Envoys sent by the Sō and Sōda Clans $(1413-38)^{100}$

\begin{tabular}{|c|c|c|c|c|}
\hline \multirow{2}{*}{ Year } & \multicolumn{2}{|c|}{ Sō clan } & \multicolumn{2}{|c|}{ Sōda clan } \\
\hline & No. of envoys & Head of the clan & No. of envoys & Head of the clan \\
\hline 1413 & 12 & \multirow{5}{*}{ Sadashige } & 1 & \multirow{16}{*}{ Saemontarō } \\
\hline 1414 & 10 & & 2 & \\
\hline 1415 & 7 & & 4 & \\
\hline 1416 & 9 & & 2 & \\
\hline 1417 & 7 & & 2 & \\
\hline 1418 & 6 & $\begin{array}{l}\text { (2-Sadashige } \\
4-\text { Sadamori })\end{array}$ & 4 & \\
\hline 1419 & 2 & \multirow{20}{*}{ Sadamori } & 2 & \\
\hline 1420 & 2 & & 1 & \\
\hline 1421 & 1 & & 5 & \\
\hline 1422 & 2 & & 3 & \\
\hline 1423 & 1 & & 7 & \\
\hline 1424 & 1 & & 3 & \\
\hline 1425 & 1 & & 3 & \\
\hline 1426 & 3 & & 6 & \\
\hline 1427 & 3 & & 4 & \\
\hline 1428 & 8 & & 8 & \\
\hline 1429 & 4 & & 2 & \multirow{10}{*}{ Rokurōjirō } \\
\hline 1430 & 12 & & 5 & \\
\hline 1431 & 3 & & 4 & \\
\hline 1432 & 8 & & 2 & \\
\hline 1433 & 4 & & 2 & \\
\hline 1434 & 10 & & 4 & \\
\hline 1435 & 8 & & 3 & \\
\hline 1436 & 14 & & 2 & \\
\hline 1437 & 32 & & 2 & \\
\hline 1438 & 21 & & 6 & \\
\hline
\end{tabular}

resort to armed resistance. Hence to avoid such a situation, I suggest the conferment of fishing rights to Tsushima islanders." 101 In requesting for the return of captives, Tsushima envoys often appealed to the human emotions of the Korean court officials to secure their release. In three separate instances, Japanese envoy Bonrei highlighted familial ties to

100 Tamura, Chūsei, 254-55.

101 CWS, Sejong sillok, Sejong 22/5/29 [1440/6/28]. 
Table 3. Comparing Number of Japanese Trade Envoys from Tables 1 and 2 (1413-38)

\begin{tabular}{c|c|c|c}
\hline Year & $\begin{array}{c}\text { Number of Japanese } \\
\text { Trade Envoys received } \\
\text { at the Chosón Court }\end{array}$ & $\begin{array}{c}\text { Number of Japanese Trade } \\
\text { Envoys sent by both the Sō } \\
\text { and Sōda Clans }\end{array}$ & Difference \\
\hline $\mathbf{1 4 1 3}$ & 18 & 13 & 5 \\
\hline $\mathbf{1 4 1 4}$ & 14 & 12 & 2 \\
\hline $\mathbf{1 4 1 5}$ & 14 & 11 & 3 \\
\hline $\mathbf{1 4 1 6}$ & 19 & 11 & 8 \\
\hline $\mathbf{1 4 1 7}$ & 11 & 9 & 8 \\
\hline $\mathbf{1 4 1 8}$ & 14 & 10 & 4 \\
\hline $\mathbf{1 4 1 9}$ & 14 & 4 & 10 \\
\hline $\mathbf{1 4 2 0}$ & 6 & 3 & 3 \\
\hline $\mathbf{1 4 2 1}$ & 6 & 6 & 0 \\
\hline $\mathbf{1 4 2 2}$ & 9 & 5 & 4 \\
\hline $\mathbf{1 4 2 3}$ & 18 & 8 & 2 \\
\hline $\mathbf{1 4 2 4}$ & 6 & 4 & 1 \\
\hline $\mathbf{1 4 2 5}$ & 5 & 4 & 0 \\
\hline $\mathbf{1 4 2 6}$ & 9 & 9 & 1 \\
\hline $\mathbf{1 4 2 7}$ & 8 & 7 & 8 \\
\hline $\mathbf{1 4 2 8}$ & 24 & 16 & 5 \\
\hline $\mathbf{1 4 2 9}$ & 11 & 6 & 8 \\
\hline $\mathbf{1 4 3 0}$ & 25 & 17 & 10 \\
\hline $\mathbf{1 4 3 1}$ & 17 & 7 & 5 \\
\hline $\mathbf{1 4 3 2}$ & 15 & 10 & 3 \\
\hline $\mathbf{1 4 3 3}$ & 9 & 6 & 11 \\
\hline $\mathbf{1 4 3 4}$ & 25 & 14 & 6 \\
\hline $\mathbf{1 4 3 5}$ & 21 & 11 & 17 \\
\hline $\mathbf{1 4 3 6}$ & 22 & 16 & \\
\hline $\mathbf{1 4 3 7}$ & 48 & 27 & 27 \\
\hline $\mathbf{1 4 3 8}$ & 44 & & \\
\hline & & & \\
\hline
\end{tabular}

justify his requests: an isolated case of a certain Mi Yach'arang from Funakoshi, Tsushima, whose eighty-year-old mother was still waiting for his return; a certain Ma Tasŭng whose father Saemonsanrō had been previo usly released in the winter of 1422; and finally the wife and child of a certain Shirōsanrō from Settsu Province, who were simply collateral hostages caught in the strife. ${ }^{102}$ Contrary to representations that overgeneralized the island's population's close ties with piracy, it was noted that dur- 
ing the 1419 invasion, several Tsushima islanders had actually assisted the Korean soldiers in subduing the pirates on the island. ${ }^{103}$

In the limited accounts depicting the everyday lives of the islanders, women too played an important role in Tsushima society. In a document dated the fifteenth day of the tenth month of 1401, it was recorded that with the appointment of a new district chief, one of the groups to be taxed was the women divers (J. katsukime). ${ }^{104}$ Women divers collected seaweed, shellfish, and other goods, and they also participated in the manufacture of salt. ${ }^{105}$ Beyond their contribution to the household, there were also accounts of female pirates who braved the seas and fought courageously alongside their male counterparts. In a report to the court about the activities of the pirates, a Japanese informant stated that "they normally sail with women and children aboard their ships when making raids. ... They are adept at archery and skilled at wielding swords. They [the women] dive deep into the ocean and drill holes in ships." 106 As early as the 1419 Chosŏn invasion of Tsushima, a court diarist for the Kyushu Deputy recorded,

"[F]our large ships with streaming brocade banners arrived unexpectedly. It seemed that their leader was a woman with immeasurable power. She boarded the enemy ships and, grappling with the enemy, threw three hundred of them into the sea to drown." 107

102 CWS, Sejong sillok, Sejong 7/4/23 [1425/5/10].

103 Tamura, Chüsei, 226-27.

104 In the Japanese records, hyakusei referred to a male villager, while katsukime no hyakusei referred to a couple of whom one was a female diver. See Saeki, Tsushima, 55.

105 Shapinsky, Lords, 149; Arne Kalland, Fishing Villages in Tokugawa Japan (Honolulu: University of Hawai'i Press, 1995), 50.

106 CWS, Chungjong sillok, Chungjong 5/8/24 [1510/9/26].

107 Shapinsky, Lords, 146-48. 
The apt choice of a female figure in the portrayal, as Shapinsky notes, was probably inspired by the fictional tale of Japanese Empress Jingū who led an invasion of Korea as recorded in the Kojiki [An Account of Ancient Matters]. As exaggerated as it might sound, it is not hard to draw a connection to the writer's dramatization of Tsushima efforts in repelling the Chosŏn navy as the numerically superior foreign troops did eventually retreat. Therefore, though limited in sources, these examples shed a different light on the Tsushima islanders, revealing how unnamed actors participated in their own ways.

\section{Conclusion}

The paradigm of a "compound state" as suggested by Japanese historian Mizubayashi Takeshi takes on a new perspective of analyzing the nature of politics in Edo Japan. ${ }^{108}$ In characterizing the different domains as independent states with much autonomy in deciding domainal affairs with minimal bakufu interference, this seems applicable to Tsushima even during the late Warring States period. The transition from the office of shugo to the elevated position of daimyō was a relatively uneventful event for the Sō clan as the leader readily accepted his new position with the immediate task of restoring relations with the Korean court as soon as the Tokugawa bakufu was established. ${ }^{109}$ The East Asian world order drew upon the Confucian demarcation of civilization and barbarism, where each political center privileged itself as the civilized vis-à-vis others who were not. Chosŏn Korea established its own centrality as "Little China" (K. sochunghwa) in dealing with foreign powers other than Ming China while the bakufu tried to construct a Japan-centric order independent of

108 Mark Ravina, "State-Building and Political Economy in Early-Modern Japan," Journal of Asian Studies 54, no. 4 (November 1995): 1009.

109 Tsuruta Kei, “"'The Establishment and Characteristics of the "Tsushima Gate,"' Acta Asiatica 67 (1994): 33. 
Chinese hegemony. Hence, there was not a single Chinese hegemonic tributary system in East Asia, but rather multiple diplomatic systems that were concurrently in place as asserted by different states. Similar to the mandala model, one can visualize early modern East Asian geopolitics as a Venn diagram in which the shapes representing the different political centers expand and contract, overlapping at times with one another, where Tsushima/Taema-do is located in the space where there were overlapping authorities. As this article has argued, Tsushima/Taema-do exerted much autonomy in deciding its relations with both the Chosorn court and the bakufu. Oscillating its identity between a vassal state of Chosŏn Korea and a province under the bakufu, the rulers of the island skillfully capitalized on the island's unique position and upheld their autonomy and interests while performing a delicate act of power balancing between the island's overlords.

The Sō clan recognized the economic and political importance of being the sole intermediary between Korea and Japan, and they watchfully safeguarded that role as seen in how they skillfully outmaneuvered other competitors both within and without the island. Although beyond the scope of this article, the role of the island was subsequently enhanced during the Edo period when the Tokugawa bakufu imposed regulations restricting Japanese contacts with the outside world. In the following game-changing historical episodes such as the Yanagawa affair in $1635,{ }^{110}$ the territorial dispute over Ullŭng-do/Takeshima in the late $1690 \mathrm{~s},{ }^{111}$ the debasing of silver ingot in $1700 \mathrm{~s},{ }^{112}$ and the Russian intrusion in $1861,{ }^{113}$ the Tokugawa bakufu would at times go to the extent of

110 In the 1635 Yanagawa Affair, the Yanagawa family was punished and sent to exile for forgery while the Sō clan emerged unscathed and stronger than before. See Tsuruta, "The Establishment," 37.

111 Despite ongoing conflicting claims over the sovereignty of the islands of Tokdo and Ulleungdo by both the bakufu and the Chosŏn court, the Sō clan emerged as a third party in offering an alternate negotiating channel to settle the dispute. See Chang Soonsoon, "17 segi huban Ullŭng-do chonggyŏlgwa (1696 nyŏn-1699 nyŏn),” Hanil gwan'gyesa yŏn'gu 45 (August 2013): 207-48. 
not only absolving the Sō clan's responsibilities but also making exceptions in acceding to their requests.

Historical works investigating the role of Tsushima in Japan-Korea relations remain scant despite the exhaustive research produced in both the Japanese and Korean academia. Most of these works take the vantage point from either the Japanese or Korean perspectives and present an argument that often depict the experience of Tsushima as an alternate history to their national narrative. In her article, Tomomi J. Emoto criticizes that this ignores the dynamic cross-border interactions and misleads one into thinking that the history of Tsushima is a linear, singular past. ${ }^{114}$ She points out that such portrayals are not limited to historical narratives but are also manifested in current municipal festivals like the Tsushima Izuhara-Port Festival where the islanders "re-enact the historical procession of Korean emissaries as the shogunate's formal guests." 115 Thus, popular depictions of such "alternate" history subliminally revere the success of the nation-state paradigm. Popular imagination of the island's history has also been in the spotlight as seen in how municipal authorities capitalize on historical fiction to boost tourism of the island by targeting Korean visitors whom they assume are familiar with the history between

112 Despite the bakufu's decision to debase silver in 1695, Tsushima was granted the exception to trade in their own specially minted silver ingots in 1711. See Tashiro Kazui, "Tsushima-han's Korean Trade, 1684-1710," Acta Asiatica 30 (1976): 85-105.

113 For an account of the 1861 Tsushima incident caused by the arrival of a Russian navy ship, see Viktor E. Shmagin, "Diplomacy and Force, Borders and Borderlands: Japan-Russia Relations in the Transformation of Japanese Political Culture in the Edo and Early Meiji Periods," Ph.D. dissertation (University of California Santa Barbara, 2016), 290-350.

114 Tomomi J. Emoto, "Border historicity and ethnographic rupture: Pirates, Korean Kings and borderlanders in transnational Tsushima Island, Japan," History and Anthropology 29, no. 4 (March 2018): 427.

115 This festival takes place annually over the first weekend in August. See Emoto, "Border," 428. 
the island and the Chosŏn court. ${ }^{116}$ From the Korean perspective, Chŏng Da-ham disapproves of how modern Korean historians "interpreted the Confucianization of Chosonn in nationalistic ways" that presented the kyorin chŏngch 'aek diplomacy framework as a peaceful Confucian protocol, feeding into the argument that Chosŏn Korea could claim "cultural" superiority over its foreign neighbors such as the Jurchen, Ryukyuan and Japanese in order to "civilize" them." 117

In conclusion, by examining the historical experience of Tsushima/Taema-do in the fifteenth century, this article exposes some of the artificiality with which national histories are fraught. Just as how the 2017 case as introduced in the opening suggests, historical episodes are easily evoked as justifications for resolving contemporary disputes. But more disturbing is the issue of how such historical legacies remain powerful in exerting modern-day nationalistic claims. Within an early-modern context, national identities were not mutually exclusive: whether one chose to be a subject of the bakufu or of the Chosón court was not an either-or question. Rather than a permanent status, such allegiances were fluid and changed with time, or were even expressed to more than one authority at the same time. Oceans did not merely serve as "a boundary-free highway for transportation and communication" connecting islands and neighboring littoral regions. ${ }^{118}$ Histories too should not be restricted to land-based events nor the boundaries of any one political entity, but can encompass activities and relationships that extend across large bodies of water. Perhaps putting the islands into the limelight of historical narratives best illuminates the story of an interconnected region. In locating peripheral history in the global context, a more objective approach that is not tainted by nationalist

116 Nakamura, "Tsushima," 34.

117 Kyorin was the diplomatic protocol between Chosŏn Korea and other foreign entities that were recognized as its equal, i.e., Ryukyu kingdom, Tokugawa $b a$ $k u f u$. This differentiates from sadae which was the official policy when dealing with a superior power such as Ming and Qing China. See Chŏng, "Making," 37.

118 Mori Katsumi, Nissō bōeki no kenkyū Mori Katsumi chosaku senshū 1 (Tokyo: Kokusho Kankōkai, 1975), 8. 
agenda nor the teleology of modernization theory is possible. As an island situated at the periphery of both Korean and Japanese political influences, Tsushima/Taema-do managed to navigate the rough seas of early modern East Asian geopolitics. Although the size of Tsushima/Taema-do was a mere fraction of its larger and stronger neighbors, evidently its geographic scale did not limit its geopolitical impact within the regional context of East Asia.

\section{References}

1. Adelman, Jeremy, and Stephen Aron. "From Borderlands to Borders: Empires, Nation-States, and the Peoples in between in North American History." American Historical Review 104, no. 3 (June 1999): 814-41.

2. Ahmed, Manan. "Adam's Mirror: The Frontier in the Imperial Imagination." Economic \& Political Weekly 46, no. 13 (March 2011): 6065.

3. Amino Yoshihiko. Nihon chūsei no hinōgyōmin to Tennō [Japan's late medieval nonagriculturalists and the Emperor]. Tokyo: Iwanami Shoten, 1984.

4. Antony, Robert J. "Introduction: The Shadowy World of the Greater China Seas." In Elusive Pirates, Pervasive Smugglers: Violence and Clandestine Trade in the Greater China Seas, edited by Robert J. Antony, 1-14. Hong Kong: Hong Kong University Press, 2010.

5. Araki Kazunori. Chūsei Tsushima Sōshi ryōgoku to Chōsen [Sō clan of Tsushima and Korea in the medieval period]. Tokyo: Yamakawa Publishing Company, 2017.

6. Baker, Don. "Confucianism and Civilization: Tasan Chŏng Yagyong's Views of Japan, the Ryūkyūs, and Tsushima." Korean Studies 40 (2016): 43-57.

7. Bashford, Alison. "Terraqueous Histories." Historical Journal 60, no. 2 (February 2017): 253-72. 
8. Chang Soonsoon. "17 segi huban Ullŭng-do chonggyŏlgwa (1696 nyŏn-1699 nyŏn) [The territorial dispute over Ulleungdo in the late $17^{\text {th }}$ century (1696-1699)]." Hanil gwan'gyesa yŏn'gu [Korea-Japan Historical Review] 45 (August 2013): 207-48.

9. Choe, Sanghun. "South Korea can Keep Buddhist Statue Stolen from Japan, Court Says." New York Times, January 26, 2017. https://www.nytimes.com/2017/01/26/world/asia/south-korea-japanbuddha-statue.html

10. Chosŏn Wangjo Sillok [Veritable records of Chosŏn dynasty].

11. Chŏng Daham. "Making Chosŏn's Own Tributaries: Dynamics between the Ming-centered World Order and a Chosŏn-centered Regional Order in the East Asian Periphery." International Journal of Korean History 15, no. 1 (February 2015): 29-63.

12. “Chosŏnch'ogi yain'gwa Taema-doe Taehan pŏlli pŏnbyŏng inshigŭi hyŏngsŏnggwa Kyŏngch'agwanŭi pagyŏn [Formation of Chosŏn's suzerainty over Jurchen and Tsushima by dispatching Kyŏngch'agwan]." Tongbanghakchi [Journal of Korean Studies] 141 (March 2007): 221-66.

13. Donnan, Hastings, and Thomas Wilson. Borders: Frontiers of Identity, Nation and State. Oxford: Berg, 2000.

14. Duchacek, Ivo D. "International Competence of Subnational Governments: Borderlands and Beyond." In Across Borders: Transborder Interaction in Comparted Perspective, edited by O.J. Martinez, 1128. El Paso: Texas Western Press, 1986.

15. Emoto, Tomomi J. "Border historicity and ethnographic rupture: Pirates, Korean Kings and borderlanders in transnational Tsushima Island, Japan." History and Anthropology 29, no. 4 (March 2018): 42545.

16. Enomoto Wataru. Higashi Ajia kaiiki to Nitchū kōryū: 9-14 seiki [Maritime East Asia and Japanese-Chinese interactions from the $9^{\text {th }}$ to $14^{\text {th }}$ centuries]. Tokyo: Yoshikawa Kōbunkan, 2007.

17. Fackler, Martin. "An Icon and a Symbol of Two Nations' Anger." New York Times, June 3, 2013. https://www.nytimes.com/2013/ 
06/03/world/asia/japan-korea-dispute-revived-by-statues-theft.html.

18. Hämäläinen, Pekka, and Samuel Truett. "On Borderlands.” Journal of American History 98, no. 2 (September 2011): 338-61.

19. Hellyer, Robert Ingels. "Poor but Not Pirates: The Tsushima Domain and Foreign Relations in Early Modern Japan." In Elusive Pirates, Pervasive Smugglers: Violence and Clandestine Trade in the Greater China Seas, edited by Robert J. Antony, 115-26. Hong Kong: Hong Kong University Press, 2010.

20 .

. Defining Engagement: Japan and Global Contexts, 16401868. Cambridge, MA: Harvard University Press, 2009.

21. Iordanova, Dina, David Martin-Jones, and Belen Vidal, editors. Cinema at the Periphery. Detroit: Wayne State University Press, 2010.

22. Itō Kōji. "Chūsei kōki no Rinzaishū Genjūha to gaikōryū [Foreign relations and the Rinzai sect's Genjū school in late medieval Japan]." Shigaku zasshi [Historical Society of Japan] 108, no. 4 (1998): 465500 .

23. Jeong Yeonghyeon. "Tonghaeanŭi waeguwa Ssŭshima Chojŏnssi [Japanese pirates on the eastern shore and the Sōda clan of Tsushima]." Han'guk minjok munhwa [Journal of Koreanology] 67 (May 2018): 199-233.

24. Kalland, Arne. Fishing Villages in Tokugawa Japan. Honolulu: University of Hawai'i Press, 1995.

25. Kang, Etsuko Haejin. Diplomacy and Ideology in Japanese-Korean Relations: From the Fifteenth to the Eighteenth Century. New York: St. Martin's Press, 1997.

26. Kim Inhyun. "Joseon Tongsinsa wa Daema-do ui gwangye [The relationship between Chosŏn envoys and Tsushima]." Ilbon-eo gyoyuk [Journal of Japanese Language Education Association] 79 (March 2017): 131-48.

27. Kimura Naoya. "Tsushima: Tsūkō'bōeki ni okeru sesshoku ryōiki [Tsushima: A region of interactions in diplomacy and trade]." In Iwanami kōza Nihon rekishi dai 20 Ken: Chiiki ron [Iwanami lectures: Japanese history volume 20: Area studies], edited by Ōtsu Tōru, 
et al., 141-66. Tokyo: Iwanami Shoten, 2014.

28. Kuno, Yoshi Saburo. Japanese Expansion on the Asiatic Continent: A Study in the History of Japan with Special Reference to Her International Relations with China, Korea, and Russia, Volumes 1 and 2. Berkeley: University of California Press, 1937.

29. Lee, Jeongmi. "Chosŏn Korea as Sojunghwa, the Small Central Civilization: Sadae kyorin Policy and Relations with Ming/Qing China and Tokugawa Japan in the Seventeenth Century." International Christian University Asia Culture Research 36 (March 2010): 30518.

30. Lewis, James B. Frontier Contact Between Chosŏn Korea and Tokugawa. Hoboken: Taylor \& Francis Ltd, 2003.

31. López-Calvo, Ignacio, editor. One World Periphery Reads the Other: Knowing the 'Oriental' in the Americas and the Iberian Peninsula. Newcastle: Cambridge Scholars, 2012.

32. Martinez, Oscar J. "The Dynamics of Border Interaction, New Approaches to Border Analysis." In Global Boundaries: World Boundaries, Volume 1, edited by Clive H. Schofield, 1-15. London: Routledge, 1994.

33. Matsuo Hiroki. "Chōsen ōchō no Nihonjin kanshi- Taira Dōzen [Japanese diplomat in the Chosŏn court- Taira Dōzen]" Ajia yūgaku [Asian Travel Periodical] 177 (2014): 129-36.

34. Mori Katsumi. Nissō bōeki no kenkyū Mori Katsumi chosaku senshū 1 [Research on Japan-Song trade relations: Selected essays by Mori Katsumi, Volume 1]. Tokyo: Kokusho Kankōkai, 1975.

35. Murai Shōsuke. Nihon chūsei kyōkai shiron [Medieval Japan borderlands historical treatise]. Tokyo: Iwanami Shoten, 2013.

36. . Chūsei wajin den [Stories of medieval Japanese]. Tokyo: Iwanami Shoten, 1993.

37. Nagatome Hisae, editor. Tsushima kokushi [History of Tsushima domain]. Tsushima-shi: “Tsushima kokushi” Kankō Iinkai, 2009.

38. Nakamura Yae. "Tsushima ni okeru chi'iki aidentiti saikōchiku-Chōsen tsūshinshi to ijin wo meguru sutōrīteringu wo 
chūshin ni [Reconstructing the regional identity of Tsushima-Focusing on the storytelling of Chosonn emissaries and famous personalities]." Irǒilmunhang yŏn'gu [Journal of Japanese Language and Literature] 99, no. 2 (November 2016): 19-37.

39. Osa Masanori. "Keitetsu Genso ni tsuite-Gaikō sō no shutsuji to hōkei [On Keitetsu Genso: The origins and religious background of the diplomat-monk]." Chōsen gakuho [Journal of the Academic Association of Koreanology in Japan] 29 (1963): 135-47.

40. Osa Setsuko. Chūsei Nitchō kankei to Tsushima [Medieval JapanKorea relations and Tsushima]. Tokyo: Yoshikawa Kōbunkan, 1987.

41.

. "Tsushima Sōshi ryōgoku shihai no hatten to Chōsen kankei

shokeneki [The development of Tsushima's Sō clan's power and its interests in establishing Korean contacts]." Journal of the Academic Association of Koreanology in Japan 39/40 (1966): 182-209.

42. . "Tsushima-tō Sōshi seikei no seiritsu [The establishment of the lineage of Tsushima's Sō clan]." Nihon rekishi [History of Japan] 208 (1965): 42-53.

43. Ravina, Mark. "State-Building and Political Economy in EarlyModern Japan.” Journal of Asian Studies 54, no.4 (November 1995): 997-1022.

44. Robinson, Kenneth R. "Organizing Japanese and Jurchens in Tribute Systems in Early Chosŏn Korea." Journal of East Asian Studies 13, no. 1 (May-August 2013): 337-60.

45 . . "Maps in Extant Volumes of the 1487 Tongguk yŏji sŭngnam and the 1499 Tongguk yŏji sŭngnam, and in Sinjŭng Tongguk yŏji sŭngnam." International Christian University Asia Culture Research 36 (March 2010): 259-72.

46. . "An Island's Place in History: Tsushima in Japan and in Chosŏn, 1392-1592.” Korean Studies 30 (January 2006): 40-66. 47. . "Centering the King of Chosŏn: Aspects of Korean Maritime Diplomacy, 1392-1592." Journal of Asian Studies 59, no. 1 (February 2000): 109-25.

48. . "The Tsushima Governor and Regulation of Japanese Ac- 
cess to Chosŏn in the Fifteenth and Sixteenth Centuries." Korean Studies 20 (1996): 23-50.

49. . "From Raiders to Traders: Border Security and Border Control in Early Chosŏn, 1392-1450." Korean Studies 16 (1992): 94-115.

50. Saeki Kōji. Tsushima to kaikyō no chūseishi [The medieval history of Tsushima and the Straits]. Tokyo: Yamakawa Shuppansha, 2008.

51. Seki Shūichi. Tsushima to wakō: Kyōkai ni ikiru chūsei bito [Tsushima and the pirates: People residing in the periphery during the medieval period]. Tokyo: Koshi Shoin, 2012.

52. . Chüsei Nitchō kaiikishi no kenkyū [Research on maritime Japanese-Korean medieval history]. Tokyo: Yoshikawa Kōbunkan, 2007.

53. Seo Youngkyo. "Silla Waeguk sai kyŏnggyein [People at the periphery between Silla and Japan]." Hangdo Busan [Port Busan] 35 (August 2018): 157-192.

54. Seoh, M.S. "A Brief Documentary Survey of Japanese Pirate Activities in Korea in the 13th-15th Centuries." Journal of Korean Studies 1, no. 1 (July-December 1969): 23-39.

55. Shapinsky, Peter D. Lords of the Sea: Pirates, Violence, and Commerce in Late Medieval Japan. Ann Arbor: Center for Japanese Studies, University of Michigan, 2014.

56. Shmagin, Viktor E. "Diplomacy and Force, Borders and Borderlands: Japan-Russia Relations in the Transformation of Japanese Political Culture in the Edo and Early Meiji Periods." Ph.D. dissertation. University of California Santa Barbara, 2016.

57. Sin Sukchu. Kaitō shokokuki: Chōsenjin no mita chūsei no Nihon to $R y \bar{u} k y \bar{u}$ [Haedong Jegukgi: Korean perspectives of Japan and the Ryukyu Islands]. Translated by Tanaka Takeo. First published 1471. Tokyo: Iwanami Shoten, 1991.

58. Song Hŭigyŏng. Nosongdang Ilbon haengnok (Rōshōdō Nihon kōroku: Chōsen shisetsu no mita chūsei Nihon) [Rōshōdō's record of Japan: A Korean envoy's perception of medieval Japan], edited by Murai Shōsuke. First published 1424. Tokyo: Iwanami Shoten, 1987. 
59. Tamura Hiroyuki. "Chūsei Nicchō bōeki no mondaiten-Toku ni Taira Dōzen wo chūshin toshite [The problem of medieval JapaneseKorean trade-With special focus on Taira Dōzen].” Keizai keiei ronsō [Economic and Business Administration Review] 13, no. 3 (1978): 19-43.

60. . Chūsei Nitchō bōeki no kenkyū [Research on medieval Japanese-Korean trade]. Kyoto: Sanwa Shobō, 1967.

61. Tanaka Takeo. Zenkindai no kokusai kōryū to gaikō bunsho [International relations and foreign diplomacy documents in the first half of the early modern period]. Tokyo: Yoshikawa Kōbunkan, 1996.

62 . . Wakō: Umi no rekishi [Pirates: History of the seas]. Tokyo: Kyōikusha Shuppan Sābisu, 1982.

63. Tashiro Kazui. "Tsushima-han's Korean Trade, 1684-1710." Acta Asiatica 30 (1976): 85-105.

64. Toby, Ronald P. State and Diplomacy in Early Modern Japan: Asia in the Development of the Tokugawa Bakufu. Princeton: Princeton University Press, 1984.

65. Tsuruta Kei. Tsushima kara mita Nitchō kankei [Looking at the Japanese-Korean relations from the perspective of Tsushima]. Tokyo: Yamakawa Shuppansha, 2006.

66. _. "The Establishment and Characteristics of the "Tsushima Gate." Acta Asiatica 67 (1994): 30-48.

67. Wallerstein, Immanuel. The Modern World-System, Volume 1. New York: Academic Press, 1974.

68. Watanabe Miki. “The Border of Japan' for Chinese Arrivals in Nagasaki, Satsuma, and Ryukyu." Itinerario 37, no. 3 (December 2013): 30-38.

69. Wolters, O.W. History, Culture, and Region in Southeast Asian Perspectives. Ithaca: Southeast Asia Publications, Southeast Asia Program, Cornell University, 1999.

70. Yamaguchi Takamasa. "Tsushima Shugo [Provincial lord of Tsushima]." In Nanbokucho-ki Kyushu-shugo no Kenkyu [Research on provincial governors in Kyushu during the Northern and Southern courts 
period], edited by Yamaguchi Takamasa, 565-98. Tokyo: Bunken Publishing Company, 1989. 


\section{Beyond Frontiers and Borderlands: A Reexamination of Tsushima's/Taema-Do's Geopolitical Position in Fifteenth Century East Asia}

Isaac C.K. Tan

Situated approximately ninety miles from Fukuoka, and just thirty miles from Busan, the island of Tsushima/Taema-do has been at the crossroad of East Asian geopolitics since the time of the Chosŏn court and the Muromachi/Ashikaga bakufu. In differentiating its position between a maritime "frontier" and a "border(is)land," this article argues how various historical agents from the island mediate the different hegemonic influences from Korea and Japan since the fifteenth century. I begin by examining Tsushima/Taema-do as a "frontier" where different influences overlapped and coexisted simultaneously. Then, I explore how the assertion of its identity as a "border(is)land" detached from the centralized political institutions empowered the island to negotiate its dealings with the respective political centers. The last section focuses on nonstate actors, specifically the local population and the pirate community, in articulating their agency by forms of negotiation and violence. Hence by reconceptualizing the island as a historical agent in its own right, this article highlights the need to consider the geographical and ideological space negotiated by the island during several major historical ruptures in the early modern period as Tsushima carved out its distinctive position in East Asian geopolitics.

Keywords: Tsushima/Taema-do, Chosŏn Korea, Muromachi/Ashikaga Japan, Borderland studies 


\section{〈국문초록〉}

\section{5세기 동아시아 대마도의 지정학적 위치에 대한 재검토}

Isaac C.K. Tan (Ph.D. candidate, Columbia University)

후쿠오카에서 약 90마일 떨어져 있고, 부산에서 불과 30마일 떨어진 곳에 있는 쓰시 마/대마도는 조선 시대부터 무로마치/아시카가 막부가 있었던 동아시아 지정학의 교차 로에 있다. 이 논문은 해양의 “경계Frontier"와 “국경지역Border(is)land”을 구분하면서, 이 섬의 다양한 역사적 요인들이 15 세기 이후 한국과 일본의 다양한 패권적 영향력을 어떻게 중재하고 있는지 다루고 있다. 나는 쓰시마- 대마도를 서로 다른 영향이 겹치 면서 동시에 공존하는 “경계”로 보려고 한다. 또한 중앙집권화되어 있는 정치적 중심 으로부터 분리되어 있는 “국경지역”이라고 자신들(대마도)의 정체성을 주장하는 것이 대마도가 각각의 정치적 중심, 한국과 일본과 거래할 때 협상력을 어떻게 강화했는지 분석한다. 그리고 비국가 행위자, 특히 지역 주민과 해적 사회에 초점을 맞추어, 협상 과 폭력의 형태로 그들의 의사를 표현하고 있는 부분 역시 주목했다. 섬과 섬의 주민 들을 자신들의 권리에 대한 역사적 주체로서 재개념화함으로써, 초기 근대 시기에 있 었던 몇몇의 주요한 역사적 파열 속에 대마도가 협상을 통해 자리한 지리적이고 이념 적인 공간을 동아시아 지정학 내에서 독특한 위치를 가진 것으로서 고려할 필요성을 강조한다.

주제어: 대마도(對馬島), 조선, 무로마치 시대, 국경연구 
